\title{
PERAN GURU DALAM PENINGKATAN KEMAMPUAN \\ MENGHAFAL ASMA'UL HUSNA MELALUI METODE DRILL (LATIHAN) PADA SISWA KELAS II MIS TANGGA BARU
}

\author{
Jubaidah \\ Institut Agama Islam (IAI) Muhammadiyah Bima \\ Email : jubaidahpgmi125@gmail.com
}

\begin{abstract}
Abstrak
Proses pembelajaran melibatkan proses kognitif yang dimana segala macam belajar melibatkan ingatan. Sangat penting bagi siswa untuk mempelajari dan memahami asma'ul husna, karena itu salah satu untuk menumbuhkan budi pekerti kepada siswa. Disekolah masdrasah ibtidaiyah swasta tangga baru kelas II, pada pemebelajaran asma'ul husna, masih banyak siswa yang belum mampu menghafal dan mengenal asma'ul husna. Metode drill (latihan) merupakan cara mengajar dimana siswa melaksanakan kegiatan-kegiatan latihan agar siswa memiliki ketangkasan atau keterampilan yang lebih tinggi dari apa yang telah dipelajari. Penelitian ini menggunakan penelitian kualitatif yang dimana penelitian ini tidak menggunakan statistik dalam pengelolaan dan analisis data. Yang menjadi subyek dalam penelitia ini siswa kelas II MIS Tangga Baru pengumpulan datanya dilakukan dengan menggunakan metode observasi, wawancara dan dokumentasi, untuk mendapatkan data yang akurat, objektif dan konkrit. Hasil penelitian ini menjukan bahwa, dengan menggunakan metode drill (latihan) ini dapat meningkatkan kemampuan menghafal siswa, dan perhatian siswa lebih fokus ketika menghafal. Adapun penerapan metode drill (latihan) sebgai berikut: 1) menjelaskan materi yang akan di ajarkan 2) memberikan contoh bagaimana cara menghafal kepada siswa dan siswa menghafal asma'ul husna bersama-sama 3) melihat ataau mengamati hambatan yang dialami oleh siswa 4) siswa yang belum mampu menghafal diberikan bimbingan atau latihan secara berulang agar siswa dapat dengaan mmudah mengingat apa yang dia hafal. Dapat dilihat bahawa metode ini dapat meningkatkan kemampuan menghafal siswa.
\end{abstract}

Kata Kunci : Peran Guru, Ama'ul Husnah, Metode Drill

\section{PENDAHULUAN}

7 ujuan pendidikan nasional dalam pembukaan UUD 1945 adalah mencerdaskan kehidupan bangsa, kecerdasan yang dimaksud disini bukan semata-mata kecerdasan yang hanya berorientasi pada kecerdasan intelektual saja, melainkan kecerdasan menyeluruh yang mengandung makna lebih luas, seperti yang tertera dalam UndangUndang nomor 20 tahun 2003 tentang sistem pendidikan nasional, pasal 3 , tujuan pendidikan nasional adalah menegembangkan potensi peserta 
didik agar menjadi manusia yang beriman dan bertakwa kepada tuhan yang maha esa, berakhlak mulia, sehat, berilmu, cakap, kreaktif, mandiri, dan menjadi warga Negara demokratis serta bertanggung jawab (Burhan Yusuf Abdul Azizu, 2016). Pendidikan sekolah dasar pendidikan yang sangat penting bagi seorang anak, disinilah seorang anak akan di didik dan di tuntut untuk belajar dan mengembangkan potensi dirinya Melalui proses belajar mengajar.

Dalam proses pembelajaran di kelas, setiap guru sekolah dasar berperan sebagai pelajar dan pembimbing, wajib melakukan layanan belajar baik secara individu maupun kelompok. Hal ini dimaksud agar hasil belajar yang dicapaai oleh siswa dapat memenuhi kriteria pencapaian tujuan yang diharapkan. Pembelajaran interaksi antara pendidik dengan peserta didik pada saat proses pembelajaran dalam menyampaikan ilmu dan pengetahuan yang disampaikan oleh pendidik, agar peserta didik dapat belajar dengan baik. Pembelajaran adalah suatu usaha yang membuat siswa belajar, sehingga situasi tersebut merupakan peristiwa belajar (event of leatning) usaha untuk terjadinya perubahan tingkah laku dari siswa. Perubahan tingkah laku dapat terjadi karena adanya interaksi antara siswa dengan lingkungannya (Suhanji, 2014). Pembelajaran merupakan proses komunikasi dua orang, mengajar dilakukan oleh pihak guru sebagai pendidik, sedangkan belajar oleh peserta didik.

Dalam dunia pendidikan sehubung dengan tugas guru, bahwa tugas seorang guru sebagai pendidik yaitu mendidik, mengajar, membimbing dan melatih untuk mengembangkan potensi dasar peserta didik, mengembangkan kepribadian peserta didik, memberikan keteteladanan dan menciptakan suasana yang konduktif (Umar, 2019). Guru juga mempunyai tanggung jawab dalam mendidik siswa, tanggung jawab sebagai pendidik dalam berbagai bidang di pendidikan yaitu, bidang pengembangan moral, bidang pendidikan, bidang kemasyarakatan, bidang keilmuan.

Pada umumnya pembelajaran disekolah dasar masih belum memperoleh hasil yang maksimal, hal tersebut dikarenakan masih banyak ditemuai proses pembelajaran yang kurang berkualitas tidak 
efisien, dan kurang mempunyai daya tarik bahkan cenderung membosankan sehingga hasil belajar yang dicapai siswa tidak optimal. Selain itu agar proses pembelajaran berjalan dengan efektif, guru harus memilih metode yang sesuawai dengan materi yang akan di jelaskan sehinga sejalan dengan arah dan tujuan pendidikan. Dengan memilih metode yang tepat sesuwai dengan materi yang akan di jelaskan, dapat memudahkan seorang guru dalam penyampaian materi tersebut, Sehingga memudahkan siswa dalam menangkap dan memahami materi yang di sampaikan oleh guru.

Proses pembelajaran melibatkan proses kognitif dan mengingat merupakan salah satu proses kognitif, yang dimana segala macam belajar melibatkan ingatan. Jika kita tidak dapat mengingat pengalaman kita, maka kita tidak akan bisa belajar. Mengingat juga merupakan memegang peran penting dalam kehidupan sehari-hari. Namun yang lebih penting dalam peranan proses pembelajaran adalah kemampuan peserta didik untuk memproduksi kembali pengetahuan yang sudah diterimanya. Daya ingat yang baik salah satu kebutuhan siswa untuk belajar optimal. Karena hasil belajar siswa disekolah diukur berdasarkan penguasaan siswa atas materi pelajaran, yang prosesnya tidak terlepas dari kagiatan mengingat (kemampuan menggunakan daya ingat) maka dengan daya ingat yang baik siswa akan belajar dengan mudah dan mencapai hasil optimal. Kemampuan kognitif termaksud konstruksi proses berpikir, mengingat, pemecahan masalah, perkembangan kognitif masing-masing anak bisa berbeda-beda tergantung bagaimana dan seberapa baik mereka memproses informasi yang didapatkan.

Kemampuan menghafal meliputi proses mengingat yang dimana Daya ingat adalah kekuatan jiwa manusia untuk menerima, menyimpan dan mereproduksikan kesan-kesan, pengertian-pengertian atau tanggapan-tanggapan, kemampuan kita untuk belajar (dalam arti luas) sangat dipengaruhi oleh daya ingat yang kita miliki. Tanpa daya ingat kita tidak dapat berkomunikasi (Triadib Dharmawan, 2015). Menghafal juga merupakan kaitannya sangat erat kaitanya dengan kerja memori dalam otak (Cucu Susanti, 2016). Namun tidak semua siswa memiliki daya ingat yang baik, dalam setiap kelas misalnya, ada siswa yang 
memiliki daya ingat yang baik dan adapula siswa yang memiliki daya ingat yang buruk. Siswa yang memiliki daya ingat yang buruk ditandai dengan kesulitan siswa dalam mengingat materi pembelajaran tentunya akan timbul masalah karena proses pembelajarannya yang lamban. guru sangat berperan penting dalam meningkatkan kemampuan menghafal siswa, penggunaan metode juga menjadi salah satu faktor siswa dalam kesulitan belajaranya, karena guru menggunakan metode yang tidak menarik, sehingga membuat siswa cenderung bosan dan siswa yang kesulitan belajar menjadi lamban dalam menerima pembelajaran.

Dari hasil pengamatan awal di sekolah MIS Tangga Baru kelas II pada materi pembelajaran asma'ul husna, masih banyak siswa yang belum mampu menghafal dan mengenal asmaul husna. Hal tersebut disebabkan oleh guru masih menggunakan metode yang konvensiaonal seperti metode ceramah, Tanya jawab dan penugasan sehingga membuat siswa cenderung bosan dan malas pada pembelajaran berlangsung, bahkan ada siswa yang berlari-lari di kelas, untuk menghilangkan kebosanannya pada sa'at proses pembelajaran berlangsung (Observasi, 2020).

Sangatlah penting bagi siswa untuk mengenal asmaul husna, karna asmaul husna ilmu yang membahas sifat-sifat Allah juga menjadi pondasi yang paling penting agar manusia bisa menuju kejalan Allah. Asmaul husna yaitu nama-nama Allah yang indah yang terdiri dari 99 nama-nama Allah yang menjadi bukti bahwa hanya Allah lah zat yang maha agung. Sangatlah penting bagi siswa mengenal dan memahami asmaul husna karena itu salah satu untuk menumbuhkan budi pekerti dan siwa dapat memahami sifat-sifat Allah.

Metode drill atau latihan ialah suatu cara mengajar dimana siswa melaksanakan kegiatan-kegiatan latihan agar siswa memiliki ketangkasan atau keterampilan yang lebih tinggi dari apa yang telah dipelajari. Metode drill adalah suatu metode dalam pengajaran dengan jalan melatih anak didik terhadap bahan pelajaran yang sudah diberikan. Dapat disimpulkan bahwa metode drill adalah suatu metode mengajar dengan tujuan melatih anak didik agar menguasai pengetahuan dan kecakapan. 
Metode drill atau disebut latihan dimaksudkan untuk memperoleh ketangkasan atau keterampilan latihan terhadap apa yang dipelajari, karena hanya dengan melakukannya secara praktis suatu pengetahuan dapat disempurnakan dan disiap-siagakan. Metode drill biasanya digunakan pada pelajaran-pelajaran yang bersifat motoris seperti: pelajaran menulis, pelajaran bahasa, dan pelajaran keterampilan, dan pelajaran yang bersifat kecakapan mental dalam arti melatih anak-anak berfikir cepat (Muslikhatun Nafi'a, 2018).

Berdasarkan masalah yang diuraikan diatas maka persoalan tersebut dapat di atasi dengan metode drill, peneliti tertarik dengan judul: Peningkatan Kemampuan Menghafal Asma'ul Husna Melalui Metode Drill (latihan) Pada Siswa Kelas II MIS Tangga Baru.

\section{TINJAUAN TEORITIS}

\section{Konsep Guru}

\section{Pengertian Guru}

Guru adalah seorang pelatih batasan mengenai profesi guru ditegaskan pula oleh pemerintah dalam Undang-Undang RI No 20 Tahun 2003 Tentang Sitem Pendidikan Nasional Pasal 1 pada ayat 6, yang mengistilahkan kata guru sama dengan pendidik. Pendidik adalah tenaga pendidikan yang berkualifikasi sebagai guru, dosen, konsoler, pamong belajar, widyaiswara, totur, instruktur, fasilitator, dan sebutan lain sesuwai dengan kekhususannya, serta berpartisipasi dalam menylengarakan pendidikan (Umar, 2019).

2. Peran Guru Dalam Proses Belajar Mengajar

Peranan guru dalam proses belajar mengajar sebagai berikut:

a. Guru Sebagai Demonstrator

Melalui peranannya sebagai demonstrator, lecturer, atau pengajar, guru hendaknya senantiasa mengusai bahan atau materi pembelajaran yang akan di ajarkannya serta senantiasa mengembangkannya dalam arti meningkatkan kemampuannya dalam hal ilmu yang dimilikinya karena hal ini akan sangat menentukan hasil belajar yang dicapai oleh siswa. 
b. Guru Sebagai Pengelola Kelas

Dalam perannya sebagai pengelolaan kelas (learning manager), guru hendaknya mampu mengelola kelas sebagai lingkungan belajar serta merupakan aspek dari lingkungan sekolah yang perlu diorganisasi. Tujuan umum pengelolaan kelas ialah menyediakan dan mnegunakan fasilitas kelas untuk bermacam-macam kegiatan belajar dan mengajar agar mencapai hasil yang baik.

c. Guru Sebagai Mediator dan Fasilitator

Sebagai mediator guru hendaknya memiliki pengetahuan dan pemahaman yang cukup tentang media pendidikan karena media pendidikan merupakan alat komunikasi untuk lebih mengefektifkan proses belajar mengajar, dengan demikian media pendidikan merupakan dasar yang sangat diperlukan yang bersifat melengkapi dan merupakan sebagian integral demikian berhasilnya proses pendidikan dan pengajaran di sekolah. Sebagai fasilitator guru hendaknya mampu mengusahakan sumber belajar yang berguna serta dapat menunjang pencapaian tujuan dan proses belajar-mengajar, baik yang berupa nara sumber, buku teks, majalah, ataupun surat kabar.

d. Guru Sebagai Evaluator

Demikian pula dalam satu kali proses belajar mengajar guru hendaknya menjadi seorang evaluator yang baik. Kegiatan ini dimaksudkan untuk mengetahui apakah tujuan yang telah dirumuskan itu tercapai atau belum, dan apakah materi yang akan diajarkan sudah cukup tepat. Semua pertanyaan tersebut akan dapat dijawab melalui kegiatan evaluasi atau penilaian (Moh. User Usman, 2007).

\section{Tugas Guru}

Tugas guru sebagai profesi meliputi mendidik, mengajar dan melatih. Mendidik berarti meneruskan dan mengembangkan nilainilai hidup/kepribadian. Mengajar berarti meneruskan dan mengembangkan ilmu pengetahuan dan teknologi. Sedangkan melatih berarti mengembangkan keterampilan-keterampilan kepada peserta 
didik. Di sekolah, guru harus dapat menjadikan dirinya sebagai orang tua kedua, ia harus mampu menarik simpati sehingga ia menjadi idola para peserta didiknya. Pelajaran apapun yang diberikan, hendaknya dapat menjadi motivasi bagi peserta didiknya dalam belajar (Hamid Darmadi, 2015).

4. Tanggung Jawab Guru

Tanggung jawab guru dan unsur pendidikan lainnya bukan hanya sekedar dalam hal mengajar atau melanjutkan dunia pendidikan di sekolah di tempatnya bertugas, tetapi juga bertanggung jawab untuk mengajak masyarakat di sekitarnya untuk ikut berpartisipasi dalam melanjutkan pendidikan di wilayahnya. Guru yang professional akan tercermin dalam pelaksanaan dalam pelaksanaan pengabdian tugas-tugas yang di tandaii dengan keahlian baik dalam materi maupun metode. Tanggung jawab guru professional ditunjukan melalui tanggung jawabnya dalam melaksanakan seluruh pengabdiannya. Tanggung jawab seorang guru professional antara lain:

1) Tanggung jawab intelektual diwujudkan dalam bentuk penguasaan materi pembelajaran secara luas dan mendalam, yang mencangkup penguasaan materi, kurikulum mata pelajaran di sekolah dan subtansi keilmuan yang menaungi materinya, serta penguasaan terhadap struktur dan metodologi keilmuan.

2) Tanggung jawab proffesi/pendidikan diwujudkan melalui pemahaman guru terhadap peserta didik, perancangan dan pelaksanaan pembelajaran, evaluasi hasil belajar, dan pengembangan peserta didik, untuk mengaktualisasikan berbagai potensi yang dimilikinya.

3) Tanggung jawab sosial diwujudkan melalui kemampuan guru berkomunikasi dan bergaul secara efektif dengan peserta didik, dan masyarakat sekitar.

4) Tanggung jawaab spiritual dan moral di wujudkan melalui penampilan guru sebagai insan beragama yang perilakunya senantiasa berpedoman pada ajaran agama dan kepercayaan yang dianutnya serta tidak menyimpang dari norma agama dan moral. 
5) Tanggung jawab pribadi di wujudkan melalui kemampuan guru memahami dirinya, mengelola dirinya, mengendalikan dirinya, dan menghargai serta mengembangkan dirinya dalam bentuk moral spiritual (Hamid Darmadi, 2015).

\section{Metode Drill Latihan}

\section{Pengertian Metode Drill}

Metode drill atau latihan ialah suatu cara mengajar dimana siswa melaksanakan kegiatan-kegiatan latihan agar siswa memiliki ketangkasan atau keterampilan yang lebih tinggi dari apa yang telah dipelajar. Metode drill adalah suatu metode dalam pengajaran dengan jalan melatih anak didik terhadap bahan pelajaran yang sudah diberikan. Dapat disimpulkan bahwa metode drill adalah suatu metode mengajar dengan tujuan melatih anak didik agar menguasai pengetahuan dan kecakapan.

Metode drill (Latihan) tepat untuk digunakan yaitu:

a. Apabila pelajaran dimaksudkan untuk melatih ulang pelajaran yang sudah diberikan dan atau yang sedang berlangsung.

b. Apabila pelajaran dimaksudkan untuk melatih keterampilan anak dalam mengerjakan sesuatu dan melatih anak-anak untuk berfikir cepat. Metode ini dipergunakan untuk memperkuat daya tanggapan anak terhadap pelajaran.

2. Prinsip Dan Petunjuk Menggunakan Metode Drill

Prinsip dan petunjuk menggunakan metode drill yaitu:

a. Siswa harus diberi pengertian yang mendalam sebelum diadakan latihan tertentu.

b. Latihan untuk pertama kalinya hendaknya bersifat diagnosis. Jika kurang berhasil, lalu diadakan perbaikan agar lebih sempurna.

c. Latihan tidak perlu lama asalkan sering dilaksanakan.

d. Harus disesuaikan dengan taraf kemampuan siswa.

e. Proses latihan hendaknya mendahulukan hal-hal yang esensial dan berguna (Muslikhatun Nafi'a, 2018).

3. Langkah-Langkah Penggunaan Metode Drill (Sintak)

Agar tujuan pembelajaran dapat tercapai, guru dapat melakukan langkah-langkah penerapan metode drill (latihan) yaitu: 
a. Guru memberikan penjelasan singat tentang konsep, prinsip, atau aturan yang menjadi dasar dalam melaksanakan pekerjaan yang akan dilatih.

b. Guru mempertunjukan bagaimana melakukan pekerjaan itu dengan baik dan benar sesuwai dengan konsep dan aturan tertentu. Pada bentuk pelajar verbal yang dipertunjukan adalah pengucapan atau penulisan kata atau kalimat.

c. Jika belajar dilakukan secara kelompok atau klasik, guru dapat memerintah seorang siswa untuk menitrukan apa yang telah dilakukan guru, sementara siswa lain memperhatikan.

d. latihan perseorangan dapat dilakukan melaui bimbingan dari guru sehingga dicapai hasil belajar sesuwai dengan tujuan (Sridatun Nisti, 2014).

\section{Menghafal Asma'ul Husnah}

Asma'ul husna artinya nama-nama allah yang indah, baik, agung dan mulia sesuwai dengan sifat-sifat nya. Dalam arti perkata "Asma" berarti nama dan "husna" berarti yang baik atau yang indah, jadi asma'ul husna adalah nama-nama milik Allah yang baik dan indah. Asma'ul husna adalah nama-nama Allah yang terbaik dan yang agung yang berjumlah sebanyak 99 (Sembilan puluh Sembilan) nama (Muhammad Hery Santoso Dkk, 2019).

Dalil yang menjelaskan tentang asma'ul husna terdapat di AlQur'an Surah Al-Isra Dan Al-A'raf sebagai berikut:

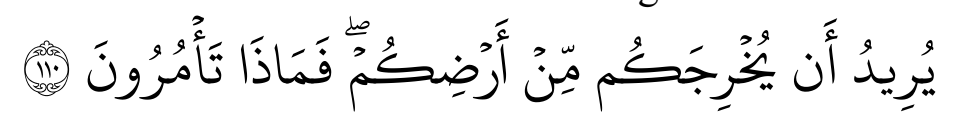

Artinya: Katakanlah "Serulah Allah atau serulah Ar-Rahman. Dengan nama yang mana saja kamu dapat menyeru, karena Dia mempunyai nama-nama yang terbaik (Asma'ul husna) dan janganlah engkau mengeraskan suaramu dalam shalatmu dan janganlah (pula) merendahkannya dan usahakan jalan tengah di antara kedua itu."(Qs. Al-isra:110)

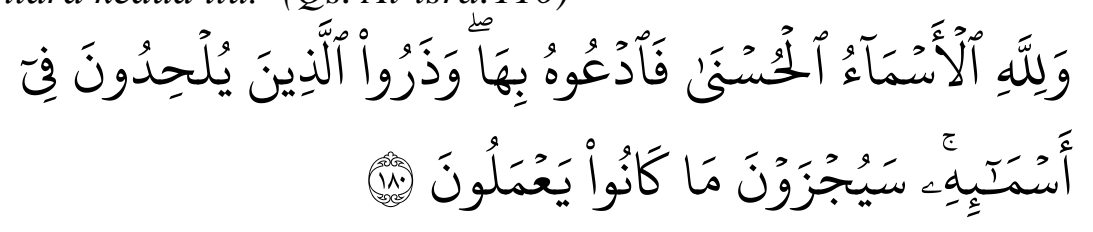


Artinya: "Dan Allah memiliki Asma'ul-husna (nama-nama yang terbaik), maka bermohonlah kepada-Nya dengan menyebutnya Asma'ul-husna itu dan tinggalkanlah orang-orang yang menyalah artikan nama-nama-Nya. Mereka kelak akan mendapat balasan terhadap apa yang telah mereka kerjakan."(Qs. AlA'raf: 180)

\section{METODOLOGI PENELITIAN}

Adapun jenis penilitian dalam penelitian ini. Penelitian Kualitatif adalah menelitian yang tidak menggunakan statistik dalam pengelolaan dan analisis data. Penelitian yang menggunakan metode kualitatif berusaha memahami dan menafsirkan makna suatu interaksi tingkah laku manusia dalam situasi tertentu menurut perspektif penelitian sendiri (Erwin Widiasworo, 2018). Adapun tekhnik pengumpulan data dalam penelitian ini adalah observasi, dokumentasi dan wawancara (Sugiyono, 2009). Kegiatan analisis dan pengumpulan data dilakukan interaktif dan merupakan siklus yang berulang-ulang, berlanjut secara terus-menerus dan saling menyusun sampai kegiatan akhir dalam penelitian siap dikerjakan. Model interaktif oleh Miles dan Huberman yakni pengumpulan data, penyajian data, reduksi data, dan verifikasi data.

\section{HASIL TEMUAN}

Di dalam sebuah pembelajaran yang ideal dibutuhkan sebuah metode yang dianggap tepat untuk mempermudah pemahaman siswa dan menerima sebuah materi yang diberikan. oleh karena itu peneliti mencari informasi bagaimana peran ibu dalam meningkatkan kemampuan menghafal asma'ul husna dengan metode drill (latihan) ini, hal ini dapat dilihat dari penyampaian ibu Nurwadidah, sebagai berikut:

"Untuk peran guru kita harus menguasai bahan dan materi yang akan di pelajari supaya dalam proses latihan menghafal dan mengajarnya dapat disampaikan dengan mudah dan proses menghafalnyapun dapat berjalan dengan lancar, dan siswa dengan mudah memahami dan menghafal asma'ul husna" (Nurwahidah, 2020).

Keberhasilan guru dalam penyampaian materi pembelajaran sangat bergantung dengan metode yang digunakan, dan langkah-langkah dalam menerapkan metode latihan ini. 1) menjelaskan materi yang akan di ajarkan misalnya asma'ul husna. 2) memberikan contoh bagaiman cara menghafal kepada siswa, setelah itu melatih siswa dalam mengahfal asma'ul husnah bersama-sama dan berkelompok,3) melihat atau 
mengamati hambatan yang dialami oleh siswa dan bertanya siapa saja yang belum lancar mengahafal. 4) siswa yang belum lancar menghafal secara perseorang guru memberikan bimbingan agar siswa dapat dengan mudah mengingat apa yang dia hafal

Berdasarkan data yang diperoleh dari lokasi MIS Tangga Baru Kecamatan Monta bahwa dalam proses pembelajaran Asma'ul Husna, guru menggunakan metode drill (latihan) ini, kemampuan menghafal anak semakin meningkat yang dimana, didalamnya ada persiapan, penerapan, faktor pendukung dan penghambat dalam menggunakan metode drill (latihan) sebagai berikut:

Untuk persiapan metode drill (latihan) adalah: 1) menjelaskan materi yang akan di ajarkan misalnya materi asma'ul husna. 2) memberikan contoh bagaiman cara menghafal sesuwai dengan konsep. 3) mengadakan latihan menghafal siswa secara bersama-sama dan berkelompok. 4) siswa yang belum lancar mengahafal kita berikan latihan secara berulang secara perseorangan dengan bimbingan dari guru sehingga mencapi tujuan yang diinginkan. Selanjutnya dalam penerapan metode drill (latihan). a) guru melatih menghafal asma'ul husna siswa secara bersama-sama sambil bernyanyi. b) guru menyuruh siswa menhgafal asma'ul husna sambil bernyanyi secara berkelompok dan mengamati siapa saja yang belum bisa menghafal asma'ul husna. c) siswa yang belum bisa menghafal asma'ul husna secara perseorangan guru memberikan bimbingan agar siswa dapat dengan mudah mengingat apa yang dia hafal. Selaras dengan teori yang menjelaskan tentang langkah-langkah penerapan metode drill (latihan) sebagai berikut: 1) guru memberikan penjelasan singat tentang konsep, prinsip, atau aturan yang menjadi dasar dalam melaksanakan pekerjaan yang akan dilatih. 2) guru mempertunjukan bagaimana melakukan pekerjaan itu dengan baik dan benar sesuwai dengan konsep dan aturan tertentu. Pada bentuk pelajar verbal yang dipertunjukan adalah pengucapan atau penulisan kata atau kalimat. 3) jika belajar dilakukan secara kelompok atau klasik, guru dapat memerintah seorang siswa untuk menitrukan apa yang telah dilakukan guru, sementara siswa lain memperhatikan. 4) latihan 
perseorangan dapat dilakukan melaui bimbingan dari guru sehingga dicapai hasil belajar sesuwai dengan tujuan (Sridatun Niati, 2014).

Perang guru sangat penting dalam pencapaian tujuan pembelajaran ini, disini guru berperan sebagai pengajaran dan pembibing, wajib melakukan layanan baik secara individu maupun kelompok, oleh karena itu untuk mencapai tujuan pembelajaran guru harus menguasai bahan dan materi pembelajaran yang akan di ajarkan agar proses pembelajaran berjanlan sesuwai dengan tujuan yang ditentukan sebelumnya. Hal ini selaras dengan teori yang menjelaskan bahwa peran guru dalam proses pembelajaran tidak terlepas dari tugasnya sebagai pengajar, pendidik, dan pembibing (Nur Azizah, 2019). Peran guru juga dalam proses pembelajaran salah satunya sebagi demonstrator, yang dimana peran guru sebagai demonstrator yaitu guru hendaknya senantiasa menguasai bahan atau materi pembelajaran yang akan di ajarkannya serta senantiasa mengembangkannya dalam arti meningkatkan kemampuanya dalam hal ilmu yang dimilikinya kerena hal ini akan sangat menentukan hasil belajar yang dicapai oleh siswa (Moh. User Usman, 2007).

Dalam proses pembelajaran tentu terdapat faktor-faktor yang mempengaruhi belajar siswa yang dihadi oleh guru di antaranya faktor penghambat dan faktor pendukung.

Faktor pendukungnya yaitu: melalui bernyanyi, dengan bernyanyi sambil menghafal siswa dapat dengan mudah mengingat apa yang dia hafal, bernyanyi juga dapat meningkatkan semangat anak dalam belajar. Selaras dengan teori yang menjelaskan bahwa bernyanyi merupakan mengeluarkan suara dengan syair-syair yang digunakan, mengelola kelas dengan bernyanyi berarti menciptakan dan mengelola pembelajaran dengan menggunakan syair-syair yang dilagukan, biasanya syair-syair tersebut di sesuaikan dengan materi yang akan diajarkan, bernyanyi membuat suasana belajar menjadi riang dan bersemangat sehingga perkembangan anak dapat di stimulasi secara lebih optimal (Vera Triatnasari, 2017). 
Faktor penghambat yaitu:

1. Daya ingat anak yang lamban.

Daya ingat yang lamban dapat mempengaruhi proses pembelajaran siswa kerana proses pembelajaran melibatkan proses kognitif dan mengingat merupakan salah satu proses kognitif, yang dimana segala macam belajar melibatkan ingatan. Mengingat juga memegang peran penting dalam kehidupan sehari-hari.

2. Sikap anak yang malas.

Sikap anak yang malas juga dapat mempengaruhi kemampuan menghafal siswa, kemalasan siswa dalam menghafal mengakibatkan siswa sulit mengingat apa yang dia pelajari.

Hal ini berdasarkan teori yang menjelaskan faktor yang mempengaruhi belajar siswa yaitu faktor internal dan eksternal:

a. Faktor Internal

1) Inteligensi merupakan kemampuan kemampuan penting yang sangat diperlukan bagi keberhasilan belajar seseorang.

2) Bakat adalah potensi/kecakapan dasar yang dimiliki sejak lahir, bakat merupakan faktor pendukung anak dalam suskses melakukan suatu hal.

3) Motivasi dalam proses pembelajaran motivasi sangat dibutuhkan, sebab seseorang yang tidak mempunyai motivasi belajar, tidak akan mungkin melakukan aktifitas belajar. Votimasi merupakan faktor pendorong akan adanya minat.

4) Sikap siswa sikap seorang siswa begitu beragam, ada yang berkeras hati, tekun dan sungguh-sungguh dalam belajar, ada juga yang malas-malasan. Hal tersebut akan banyak sekali ditemui oleh para guru dilapangan (Putri Amelia, 2018).

b. Faktor Eksternal

1) Keadaan keluarga, lingkungan keluarga sangat mempengaruhi kegiatan belajar anak, ketentangan keluarga, sifat-sifat orang tua, demongrafi keluarga, pengelolaan keluarga, semuanya dapat memberikan dampak terhadap aktivitas belajar.

2) Guru (pendidik) dan cara mendidik, seorang guru memiliki tanggung jawab yang sangat berat, bukan hanya 
mengembangkan kewajiban di dalam kelas, namun guru juga memengang peran penting di sekolah dan juga masyarakat. Bagaiman dan sikap kepribadian guru, tinggi rendahnya pengetahuan yang dimiliki guru dan bagaimana cara guru itu mengajar pengetahuan itu kepada anak didik turut menentukan bagaimana hasil belajar yang dicapai oleh anak.

Lingkungan sosial, lingkungn sosial yang kurang mendukung seperti kondisi lingkungan yang kumuh, serba kekurangan dan anakanak pengganggun akan sangat mempengaruhi aktivitas belajar siswa. Siswa tersebut akan mengalami kesulitan belajar ketika membutuhkan teman belajar untuk berdiskusi, meminjam alat-alat belajar yang belum dimilikinya (Putri Amelia, 2018).

\section{SIMPULAN}

Berdasarkan hasil penelitian yang dilakukan peneliti di Sekolah Madrasah Ibtidaiyah Tangga Baru maka memperoleh kesimpulan sebagai berikut: peningkatan kemampuan menghafal asma'ul husna melalui metode drill pada siswa kelas II, sudah dikatakan berhasil karena pada saat proses pembelajar guru sudah terlebih dahulu merancang pelaksaan pembelajaran sesuwai dengan materi yang akan di ajarkan sehingga tujuan pembelajaran yang di targenkan tercapai. Melalui penggunaan metode ini juga, guru memberikan latihan menghafal siswa secara berulang dan siswa yang belum bisa menghafal secara perseorangan, guru memberikan bimbingan agar siswa dapat dengan mudah mengingat apa yang dia hafal, sehingga kemampuan menghafal anak meningkat.

DAFTAR PUSTAKA

Burhan Yusuf Abdul Azizu. 2016. Tujuan Besar Pendidikan Adalah Tindakan, Jurnal Prosiding Ks: Riset \& Pkm, No. 2, Volume 2.

Cucu Susanti. 2016. Efektivitas Metode Talaqqi Dalam Meningkatkan Kemampuan Menghafal Al-Qur'an Anak Usia Dini, Tunas Siliwangi, No. 1, Volume 2.

Erwin Widiasworo. 2018. Mahir Penelitian Endidikan Modern, Yogyakarta, Araska Sekar Bakung Residence.

Hamid Darmadi. 2015. Tugas, Peran, Kompetensi, dan Tanggung Jawab Menjadi Guru Professional, Jurnal Edukasi, No. 2, Volume 13.

Moh. User Usman. 2007. Menjadi Guru Professional, Bandung, PT Remaja Rosdakarya. 
Muslikhatun Nafi'a. 2018. Iplementasi Metode Drill Dalam Meningkatkan Hasil Belajar Dalam Mata Pelajaran Aqida Akhlak Peserta Didik Kelas I Mi Ypi Sumber Sari Bantul Metro Selatan, Skripsi Institut Agama Islam Negeri Metro Lampung.

Muhammad Hery Santoso Dkk. 2019. Pengembagan Aplikasi Asma'ul Husnah Untuk Smartphone Dengan System Operasi Adroid, Jurnal Media Aplikom, No. 1, Volume II.

Nur Azizah. 2019. Peran Guru Dalam Mengembangkan Keterampilan Bahasa Siswa Melalui Kegiatan Literasi Di Kelas 1 SD Tara Salvia, Skripsi, UIN Syarif Hidayatul Jakarta.

Nurwahidah. 2020.Wawancara Dengan Guru Akidah Akhlaq MIS Tangga Baru.

Putri Amelia. 2018. Faktor-Faktor Yang Mempengaruhi Minta Belajar Siswa Pada Mata Pelajaran Pai Di SMP Citra Bangsa, Skripsi, Universitas Islam Negeri Syarif Hidayatullah Jakarta.

Sridatun Niati. 2014. Penerapan Metode Drill Untuk Meningkatkan Prestasi Belajar Matematika Siswa Kelas V Min Kolomayan Wonodadi Blitar, Skripsi, Institut Agama Islam Negri (IAIN) Tulungagung.

Sugiyono. 2009. Metode Penelitian Pendidikan Pendekatan Kuantitatif, Kualitatif, dan R\&D”, Bandung, Alfabeta.

Sunhaji. 2014. Konsep Manajemen Kelas Dan Implikasihnya Dalam Pembelajaran, Jurnal Kependidikan, No. 2, Volume II.

Triadib Dharmawan. 2015. Music Klasik Dan Daya Ingat Jangka Pendek Pada Remaja, Jurnal Ilmia Psikologi Terapan, No. 2, Volume 03.

Umar. 2019. Pengantar Profesi Keguruan, (Depok: Rajawali Pers.

Vera Triatnasari. 2017. Penggunaan Metode Bernyanyi Dalam Meningkakan Hasil Belajar Siswa Pada Pembelajaran Matematika Kelas III B Min Bandar Lampung, Skripsi, Institut Agama Islam Negeri Raden Intan Lampung. 